3. 酸素吹精により，酸性操業です相当の脱硫，“脱燐 が認められるが; 眖燐には熔滓中に過量の鉄酸化物を形 成させる必要がある:

4. 酎火壁を水冷することにより，裏張耐火壁が永久 壁化され，水冷羽口の使用により浸触・熔損㤬完全に防 止され，長時間の使用以充分堪え，寿命は大きく延長さ れる.

5. 被覆保護層は酸性で $5 \sim 8 \mathrm{~mm}$ ，塩基性で 8〜 $11 \mathrm{~mm}$ の厚さを示し,水量に対するとの温度绞化がかな ク小さい. その組緉からすれば，この厚さが冷却勄果の およぶ籍囲でしかる維持可能部分であることを示す。

最後に本実験の実施に当り，原料・副資材の御援助を 与克て下さつた富士製鉄室蘭製鉄所, 日本電興小国製造
所ならびに井川鉄工所，また種々御教示定賜つた前四元 三氏，金森九郎氏; 実験に加わら秃た本教室の諸兄に深: 謝する。

$$
\text { 文献 }
$$

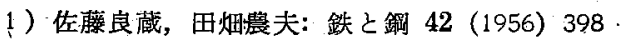

2）佐藤良藏: 錆物 30 (1958) 3

3) S. V. Gebov: British Ceramic Abstracts 4 (1948), 132

4) C. E. Sims \& F. L. Toy: Journal of Metals. 4 (1950), 694

Sub Comittee: Journal of Iron \& Steel Inst., (1947) 155 157

\title{
軸受鋼中のA系非金属介在物の電子顕微鏡的考察*
}

\author{
出口喜勇限** . 西村 富隆**.須山 弘**
}

\section{Electron-Microscopic Observation of A-Type Nonmetallic Inclusions in Ball-Bearing Steel.}

\author{
Kiyoji Deguchi, Tomitaka Nishimura and Hiroshi Suyama
}

\section{Synopsis :}

A-type nonmetallic inclusions in ball-bearing steel were examined by an optical microscope, acid test and extraction method, however it was not easy to identify each inclusion by these methods. Therefore, the inclusions microscopically observed were extracted on carbon filnis and observed by an electron microscope, and then each inclusion was respectively identified by electron diffraction.

Moreover, to confirm the results obtained, the materials similar to these inclusions identified were composed experimentally and examined by an optical microscope, X-ray and electron diffraction.

In consequence, the following conclusions were obtained:

A-type nonmetallic inclusions in ball-bearing steel were classified into two groups. That is, the one belonged to such substance as $\alpha$-cristobalite $\left(\alpha-\mathrm{SiO}_{2}\right)+\operatorname{rhodonite}\left(\mathrm{MnO} \cdot \mathrm{SiO}_{2}\right)$ and the other as manganese sulfide(MnS) +iron sulfide (FeS) or manganese sulfide only. Therefore, it was supposed that the compositions of many silicate type inclusions in this steel were in coexisted range of $\mathrm{SiO}_{2}$ and $\mathrm{MnO} \cdot \mathrm{SiO}_{2}$ in $\mathrm{MnO}-\mathrm{SiO}_{2}$ system, and those of sulfide type inclusions in coexisted range of $\mathrm{MnS}$ and FeS or $\mathrm{MnS}$ range in MnS-FeS system.

Besides the nonmetallic inclusions above mentioned, there were a few inclusions which were composed from other components and could not be identified by electron diffraction.

\section{I. 緒}

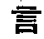

俥受鏡中の非金属介在物はベアリングの寿命就よび音 鄄果に対して影響を与えるといわれているが; 艺の際 問題になるのは鋼中の全介在物量もさることながら介在
物の分布状態および種類であると考えられている.それ ゆえこれらの位置から問題となる非金属介在物だけを単

* 昭和 33 年 10 月本会講演大会にて発表

** 日本特殊鎆株式会社 
独にとり出して，その内部棈造ならびに組成籁囲を明ら かにするここは，非金属介任物の生成機構を解明し，そ の防止対策を考究与る上に有效な资料を与える.

しかしながら従来行なわ机ている残渣分析法あるいは 残渣のX 線回折法などは，個々の非金属介压物の内部構 造を知るた河には必ずしも適当な研究手段ではなく，現 在宝で多くの基礎的な研究が行なかれているにもかかわ らず，実際の軸受銅中の非金属介在物の組成範囲につい てはいをだ完全に究明されてはいない。そこでかかる研 究の第一歩上して，カーボン聴着䐳によるエキストラク ションレプリカ泣(122)で抽受銅中の各整の非金属介在物 を抽出し，これについて霍子頙微鏡観繁执よび電子回折 による同定壳試みた。その結果，B扮よびC系介在物に ついてはこれらが粒状で厚かのたた蛙とんど回折像は えら机なかつたが，A系分佂物については火部分のもの に対して雷子回折がだきたのて，今回はA采のものだけ にしぼつて研究した。

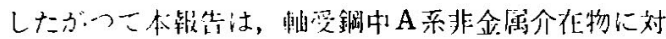

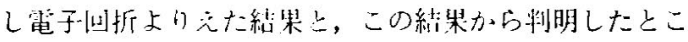

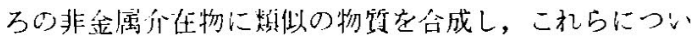

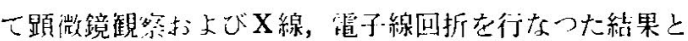

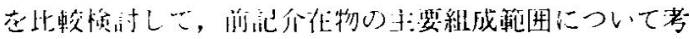
然したもりて方る。

\section{II. 試料}

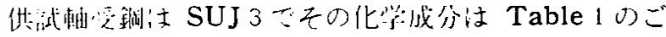

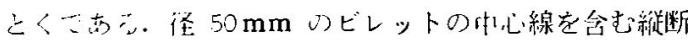

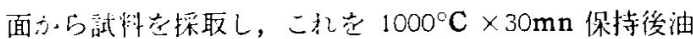

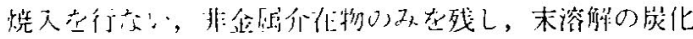

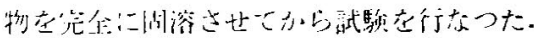

Table 1. Chemical composition of specimens $(\%)$.

\begin{tabular}{c|c|c|c}
\hline $\mathrm{C}$ & $\mathrm{Si}$ & $\mathrm{Mn}$ & $\mathrm{P}$ \\
\hline 1.02 & 0.54 & 0.99 & 0.022 \\
\hline $\mathrm{S}$ & $\mathrm{Cr}$ & $\mathrm{Ni}$ & $\mathrm{Cu}$ \\
\hline 0.012 & 1.00 & 0.07 & 0.12 \\
\hline
\end{tabular}

\section{III. エキストラクションレプリカの作製}

光学䫓溦鏡によえ非金凮介在物の組絨，色彩などの観 察は非金属介在物を判定与る隆に重要な手がかりとなる ことはもちろんであるが，さらにこの結果と同一の非金 属介在物についての電子回折による同定結果とを完全に
対応させるならば非金属介在物をより一層正しく判定す ることができる.しかしながら光学䫓微鏡で観察した非 金属介在物をそのまま電子顕微镜視野に捕えるような試 みは従来あまり行なわれていないそこで腐触被，レプ リカ膜侴離法などについても種々検討したのち，これを つぎよう方方法で効果的に実施した。

寸なわち試料を研磨後光学顕徽鏡で観察しながら目的 とする非金属介任物の周囲にダイアモンドコーンでマー クをつけ $5 \%$ ピクリン酸アルコールでー次腐強を行な い，つぎにエチルセルローズ・トリクロールエチレン溶 液を利用したブランクレプリカによつて衣面の付着物を 除去し，しかる後カーボン蒸着を行つた．その㣪ふたた び光学頙微鏡で観繁しながらマークの位置を中心として $1.5 \mathrm{~mm}$ 程度の四伯な傷をつけ他の部分のカーボン膜を 全部除去して，5\%硝酸アルコール中に浸清しレプリカ

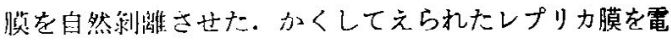
子頙微鏡用のシートメッシ上に移す際に，目的とする非 金属介在物が丁度メッシ孔の中に入らなければ,これの 電子瀕微鏡観等ができなくなるので Booker ${ }^{33}$ の発表し た方法を基にして Photo.1 のごとき装置を試作し、こ 机に上り目的上ナる非金属介在物を確実にメッシ孔の中 に捕えるようにした。

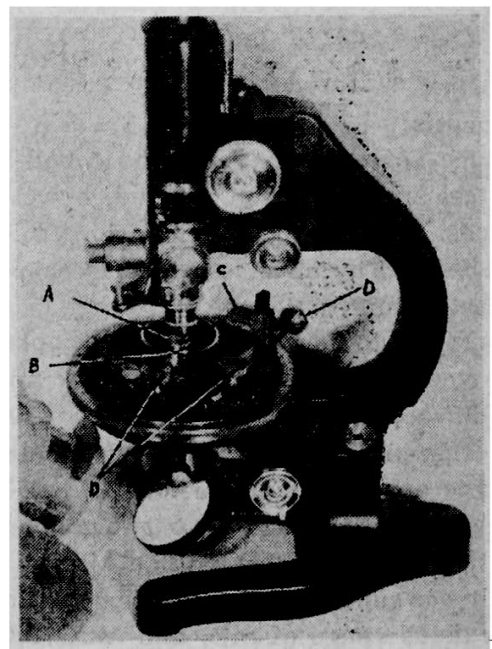

Photo. 1. Apparatus for replica preparation.

すな扒七透過頙微鏡の载物台上に水の入つたシャーレ を置き，レプリカ膜を移動防止用彗曲板（A）の中心孔 内の水面にひるげる.この下にあるシートメッシ支持台 （B）は中空の同筒で腕（C）を通して3個の微動祅 (D) によつて上下，水平方向に自由に移動しうる. 操 作はまず顕微鏡観察によつてレプリカ膜上の非金属介在 物とシートメッシの孔とが一直線上にくるように支持台 
を的節し、のぎに観察しながら支持台を微動ネヂによつ て徐々に上げれば目的とする非金属介在物は確実にシー トメッシ孔の中に捕えられる.この装置はエキストラク ションレプリカ用として非常に勃果的であつた。なおレ プリカ作製中に, 所要レプリカ膜の一端に Au を蒸着し 電子回折用標準試料とした。

\section{IV. 実験結果および考察}

\section{(1) 腐触試験による判定}

供試材中のA票非金属介在物を光学顕微鏡で観察する とほとんどすべての介在物はやや褐色がかつた灰色を呈 し，さらに詳細に観察すると内部には黑褐色の微細な班 点が存在している.したがつてこれらが単一の相から成 るものではないことが推測される.

つきにこれらについて腐触試験せを行なつたところ， これらのA系非金属介在物は10\%クローム酸によつてほ とんど全部が喑褐色に変つてしまうが，その中には $5 \%$ 塭酸アルコールあるいは 20\% 弗化水菜水溶液によつて もなおそのまま残存するものがあるので，色彩，形状の 锥察および腐蝕判定法によるだけでは組成についての推 測はもち万ん珪酸塩介在物と硫化介在物の区別もかなり 困雖であつた．なお参考までに温硝酸法による残椬分析 を試みた結果を Table 2 に示す。

(2) 電子回折による同定

供試材中から多数の非金属介在物を一つ一つエキスト ラクションレプリカで抽出し電子回折を行ない，その結 果を非金属介在物として存在すると考えられる各種の化 台物についての A.S.T.M. の X-ray powder diffraction cardと対照した.えられた結果には多少の例外 はあつたが，珪酸塭介在物系之硫化介在物系の2つに大 別することができた。これらの多数の回折結果のうちか 5代表的な $2 ， 3$ の例を選出して以下に説明する.

その第10場合は Photo. 2 に示すごとき場合であ る. すなわち光学顕微鏡組織同 (a)のことく,この非金 属介在物はやや褐色を帯びた灰色を呈し，一部には他の 酸化物と思われる褐色の大きな粒子が認められる。この 非金属们在物をエキストラクションレプリカで抽出し電 子䫓微鏡観察した結果は同（b)のごとくで1次，2次腐 蚛による形状の变化と一部の脱落が認められるが，明ら かに光学顕徽鏡で観察したものと同一物である.これの

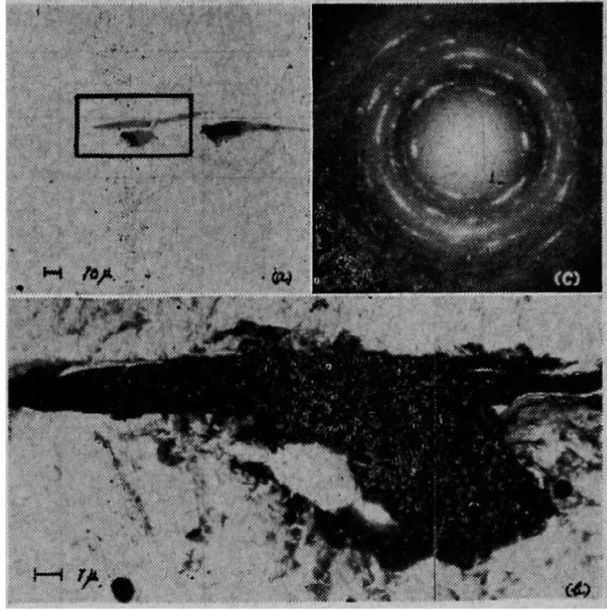

Photo. 2.

(a) Light micrograph of silicate-type nonmetallic inclusions.

(b) Electron micrograph of the nonmetallic inclusion shown in mark of (a).

(c) Electron diffraction pattern of the nonmetallic inclusion shown in (b).

電子回折像は同 (c)のごとく明確な孤状を示し，この非 金属介在物が压延によつて伸ばされ結晶学的な繊維構造 になつていることがわかる。この解析結果は Table 3

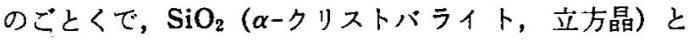
$\mathrm{MnO} \cdot \mathrm{SiO}_{2}$ (ロドナイト, 三斜唱) からなつている.

Photo. 3 はこの第1の場合の例外的なものであり, 光学顕微鏡組織同（a)では基地は褐色完燕びた灰色で内 部には微細な黑褐色の粒子が認められる.同(b)はこれ を抽出して電子顕微鏡観察したもので，電子回折像は同 (c)のごとくである.これを解析した絬果 $\mathrm{SiO}_{2}(\alpha-ク リ$ ストバライト，立方晶）， $\mathrm{Cr}_{2} \mathrm{O}_{3}$ (クローム酸化物，六方 晶) 交よび $2 \mathrm{MnO} \cdot \mathrm{SiO}_{2}$ (テフロイト，斜方晶）などで あることが解つた。

つぎ第 2 の場合に属する介在物としては Photo. 4, 5 に示すごときものがある. 光学顕微鏡組織 Photo. 4 （a）は集団をなして存在するやや褐色を带びた灰色の非 金属介在物であり，こ扎をエキストラクションレプリカ で抽出し電子顕微鏡観察した結果は同（b)で，1次およ び 2 次腐蝕による一部の溶出が認められるが明らかに同 一物であることがわかる.これの電子同折像は同(c)で

Table 2. Chemical composition of residue extracted by hot nitric acid $(\%)$.

\begin{tabular}{c|c|c|c|c|c}
\hline Total oxide & $\mathrm{SiO}_{2}$ & $\mathrm{FeO}$ & $\mathrm{Al}_{2} \mathrm{O}_{3}$ & $\mathrm{Cr}_{2} \mathrm{O}_{3}$ & $\mathrm{MnO}$ \\
\hline 0.00765 & 0.00078 & 0.00030 & 0.0033 & 0.000039 & 0.0030 \\
\hline
\end{tabular}


Table 3. Lattice spacings of the extracted nonmetallic inclusion shown in Photo. 2.

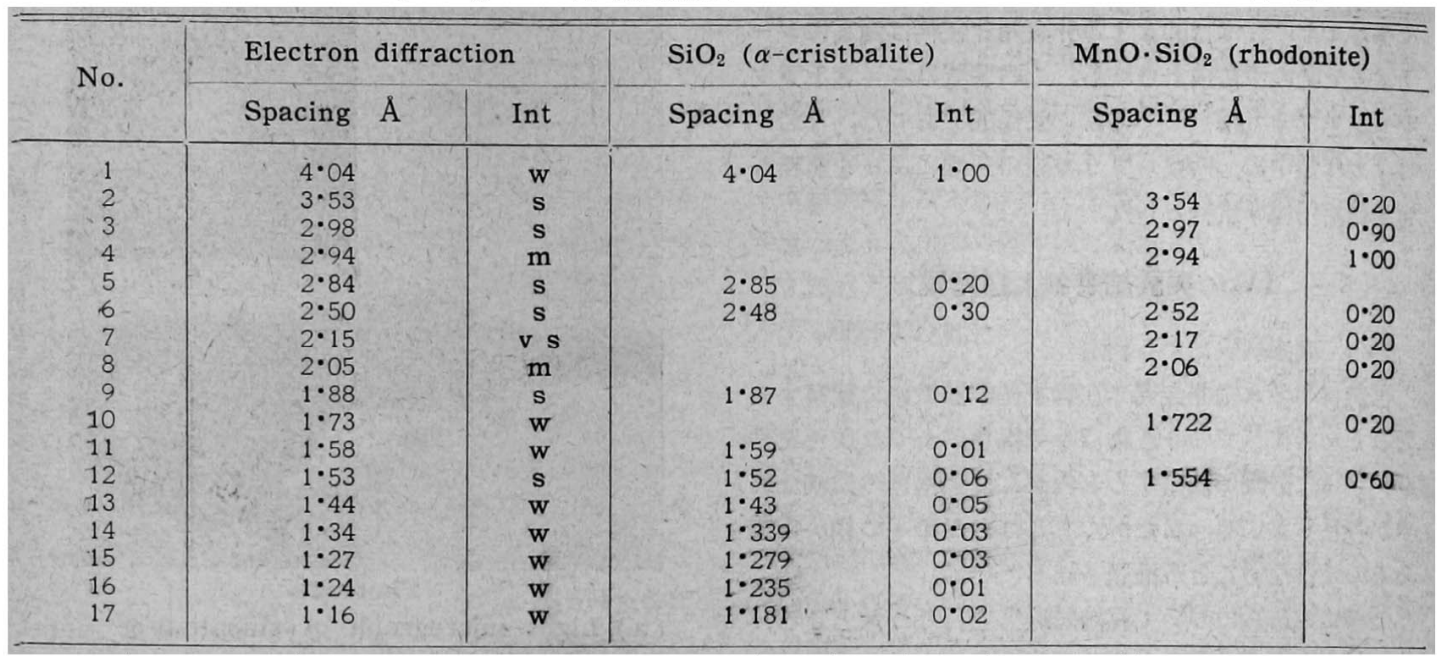

vs (very strong), s (strong), m (medium), w (weak) and vw (very weak); diffraction line intensities.

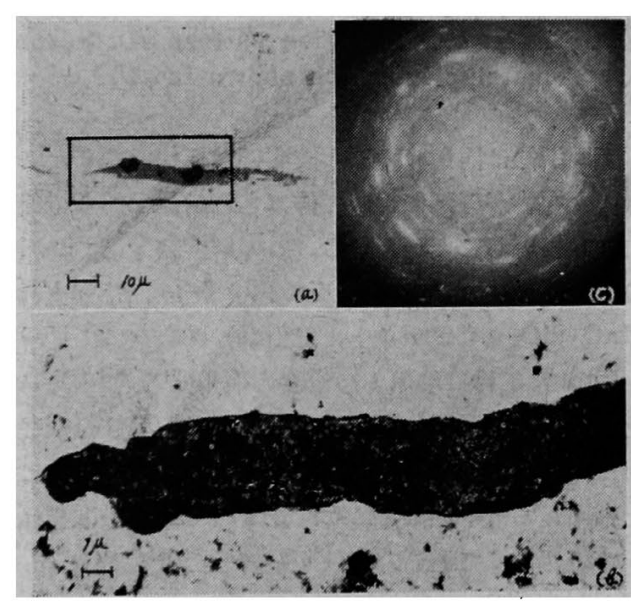

Photo. 3.

a a Light micrograph of silicate-type nonmetallic inclusion.

(b) Electron micrograph of the nonmetallic inclusion shown in mark of (a).

(c) Electron diffraction pattern of the nonmetallic inclusion shown in (b).

これを解析した結果は Table 4 のごとくで MnS（立 方晶) と FeS (六方晶) 加ら成つている.

Photo. 5(a) むこれと同じ外観を呈する非金属介在物 であるが，霆子回折像同（c）は MnS の存在のみを示し FeS は認められなかつたしたがつて第2の場合には $\mathrm{MnS}$ と FeS が共存する場合と $\mathrm{MnS}$ が単独で存在す る場合とがあつた。

なお以上述べた 2 つの場合のいうれについても，電子

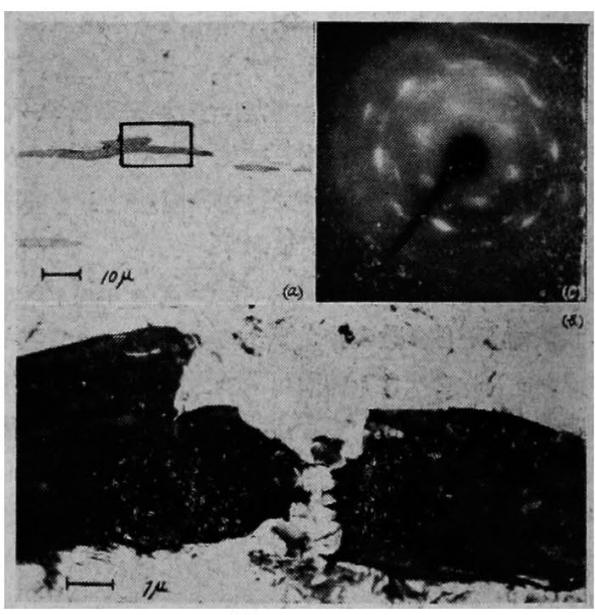

Photo. 4.

(a) Light micrograph of sulfide-type nonmetallic inclusions.

(b) Electron micrograph of the nonmetallic inclusion shown in mark of (a).

(c) Electron diffraction pattern of the nonmetallic inclusion shown in (b).

回折による回折線の相対強度とX線データーのそれとの 間には多少の相違が認められた. 以上の他, 別の化合物 かららる非金属介在物, 電子回折像はえられたが同定で

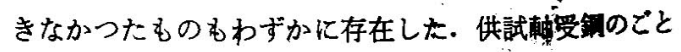
く Al, Si, Mn, Cr などの0.との親和力の强い元来柿 共存している場合には， $\mathrm{A}$ 系非金属介在物はこれらの硪 化物の固溶体あるいは化合物になり複隻なるのになると 予想されるが，以上の結果では含 $\mathrm{Al}_{2} \mathrm{O}_{3}$ 系珪酸筥化合 
Table 4. Lattice spacings of the extracted nonmetallic inclusion shown in Photo. 4.

\begin{tabular}{|c|c|c|c|c|c|c|}
\hline \multirow{2}{*}{ No. } & \multicolumn{2}{|c|}{ Electron diffraction } & \multicolumn{2}{|l|}{$\mathrm{MnS}$} & \multicolumn{2}{|c|}{$\mathrm{FeS}$} \\
\hline & Spacing $\AA$ & Int & Spacing $\AA$ & Int & Spacing $\AA$ & Int \\
\hline $\begin{array}{l}1 \\
2 \\
3 \\
4 \\
5 \\
6 \\
7 \\
8 \\
9 \\
10 \\
11 \\
12 \\
13 \\
14 \\
15\end{array}$ & $\begin{array}{l}3 \cdot 00 \\
2 \cdot 86 \\
2 \cdot 63 \\
2 \cdot 04 \\
1 \cdot 87 \\
1 \cdot 76 \\
1 \cdot 61 \\
1 \cdot 56 \\
1 \cdot 51 \\
1 \cdot 30 \\
1 \cdot 28 \\
1 \cdot 21 \\
1 \cdot 08 \\
1 \cdot 05 \\
1 \cdot 01\end{array}$ & $\begin{array}{c}\mathbf{v} s \\
\mathbf{w} \\
\mathrm{m} \\
\mathbf{v} \mathbf{w} \\
\mathbf{s} \\
\mathbf{v} \mathbf{w} \\
\mathbf{v} \mathbf{w} \\
\mathbf{s} \\
\mathbf{w} \\
\mathbf{w} \\
\mathbf{v} \mathbf{w} \\
\mathrm{m} \\
\mathbf{w} \\
\mathbf{w} \\
\mathbf{w}\end{array}$ & $\begin{array}{l}1 \cdot 58 \\
1 \cdot 51 \\
1 \cdot 309 \\
1 \cdot 20 \\
1 \cdot 0 ?\end{array}$ & $\begin{array}{l}0.11 \\
1.00 \\
0.67\end{array}$ & $\begin{array}{l}2 \cdot 97 \\
2 \cdot 88 \\
2 \cdot 65 \\
2 \cdot 06 \\
1 \cdot 71 \\
1 \cdot 61 \\
1 \cdot 299 \\
1 \cdot 05 \\
0 \cdot 995\end{array}$ & $\begin{array}{l}0.33 \\
0.04 \\
0.33 \\
1.00 \\
0.33 \\
0.07\end{array}$ \\
\hline
\end{tabular}

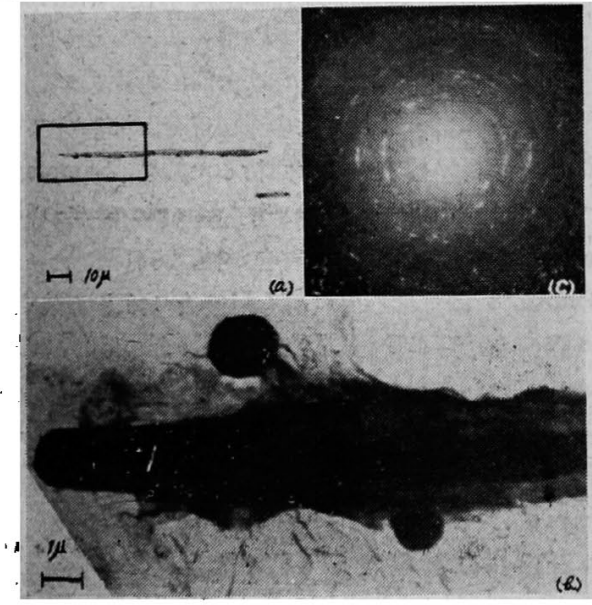

Photo. 5.

(a) Light micrograph of sulfidet-ype nonmetallic inclusions.

(b) Electron micrograph of the nonmetallic inclusions shown in (b).

物の存在はほとえど認められなかつた。この他 Porte-

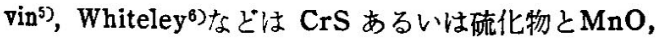

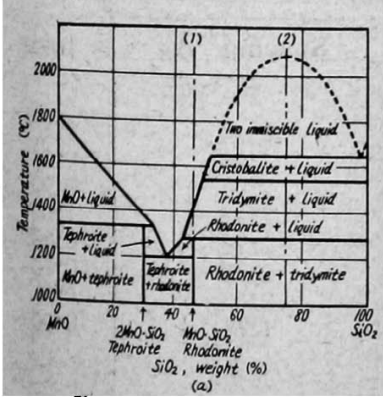

Fig. 1. Phase diagrams of $\mathrm{MnO}-\mathrm{SiO}_{2}$ (a) and FeS-MnS system (b).
Table 5. Chemical compositions of silicate samples $(\%)$.

\begin{tabular}{c|c|c}
\hline No. & $\mathrm{SiO}_{2}$ & $\mathrm{MnO}$ \\
\hline 1 & $48 \cdot 50$ & $48 \cdot 81$ \\
2 & $72 \cdot 65$ & $23 \cdot 74$ \\
\hline
\end{tabular}

FeO との共晶などについて報告しているが，調査した 範囲ではこれらは認められなかつた。

以上の結果から本軸受銅中の珪酸塩系介在物の主要組 成は $\mathrm{MnO}-\mathrm{SiO}_{2} 2$ 元系の $\mathrm{MnO} \cdot \mathrm{SiO}_{2}, \mathrm{SiO}_{2}$ 共存範井 にあり，また硫化物系介在物のそれは MnS-FeS 系の MnS, FeS 垬存範囲にあるかあるいは MnS 単独で構 成されていると考えられる。

(3) 合成試料についての検討

以上の結果を傕証し，さらに検討を加えるために，こ れらの非金属介在物と類似の物質を合成して，これにつ いて顕微鏡組織の観察，X 線および電子線回折を試み た. 試料の熔製は純黑鉛ルッボを用いてタンマン师中で 行ない原料の酸化，分解を防ぐためにアルゴン気流中で 行なつた。

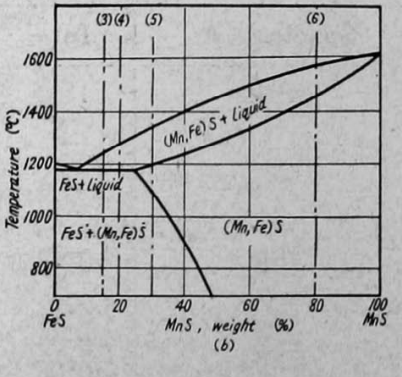

まず珪酸塭化合物系についてはシリカと， $\mathrm{MnCO}_{3}$ を真空中で熱分解して作つた $\mathrm{MnO}$ 原料として銓中の非金属介在物の電子回折結果 からえられたものと同様な組 成として Fig.1 (a)の $\mathrm{MnO}-\mathrm{SiO}_{2}$ 系平衡状態圈 ${ }^{7}$ より $\mathrm{MnO}$. $\mathrm{SiO}_{2}$ および $\mathrm{MnO} \cdot \mathrm{SiO}_{2}+\mathrm{SiO}_{2}$ の組成範囲に ある $46 \% \mathrm{SiO}_{2}$ および $75 \% \mathrm{SiO}_{2}$ 配合のむの を選び，この 2 試料を熔製し，しかる後それら を結晶化するためにすべて $1150^{\circ} \mathrm{C} \times 3 \mathrm{~h}$ 保持 
した. 試料の分析結果は Table 5 のごとくである. これらの試料の粉末をX線回折した絬果は Photo. 6 のごとくで sample 1 は $\mathrm{MnO} \cdot \mathrm{SiO}_{2}$, sample 2 は $\mathrm{MnO} \cdot \mathrm{SiO}_{2}+\mathrm{SiO}_{2}$ であつた.な抗こ秃らの試料の研磨 のままの光学顕微鏡組織は Photo. 7 に示すごとくで sample 1 についてはロドナイトの結晶が認められ，同 2 についてはロドナイトの基地に針状の $\alpha$-クリストバ

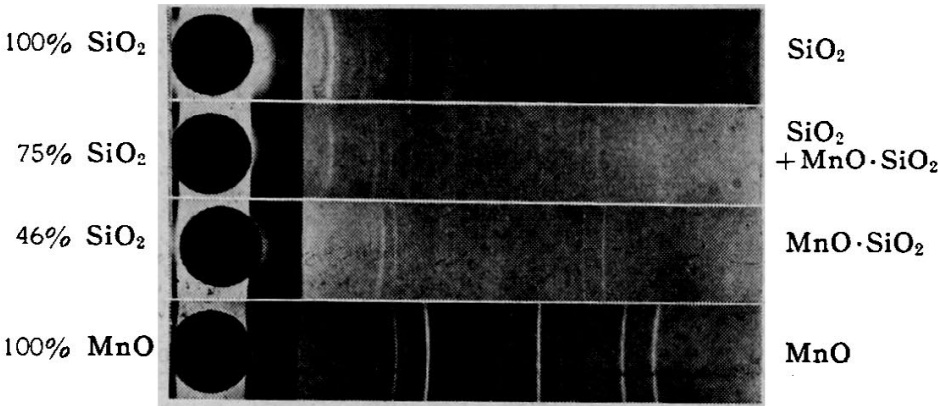

Photo. 6. X-ray diffraction photographs of silicate samples.
ライトが認められた.つきにこれらの粉末をカーボン膜 上に取り電子回折を行なつたが，解析した結果はX線に よる結果と全く同様であつた。1 例として Table 6: sample 2 の場合を示す。

つぎ硫化物系については $\mathrm{FeS}$ と， $\mathrm{MnCl}_{2}$ 水溶液 に NH4 を加えて作つた MnS を原料として，鎆中の 非金属介在物について諗められたもの上同棑学組成の のとして Fig. 1(b) の MnS-FeS 系状態洞 ${ }^{(3)}$ か. $5 \mathrm{MnS}, \mathrm{FeS} 2$ 相共 存距囲にあ 配合の3試料子よび $\mathrm{MnS}$ 固溶休単 相から成ると考えら扎る80\% MnS 配合の試料妾選び，珪酸㦈化台物の 嚗合と同様に燿製した。試料の分析 結果は Table 7 のごとくで，sa. mple 6 は一部に金属質の部分を生 じたため予定成分と相違している。

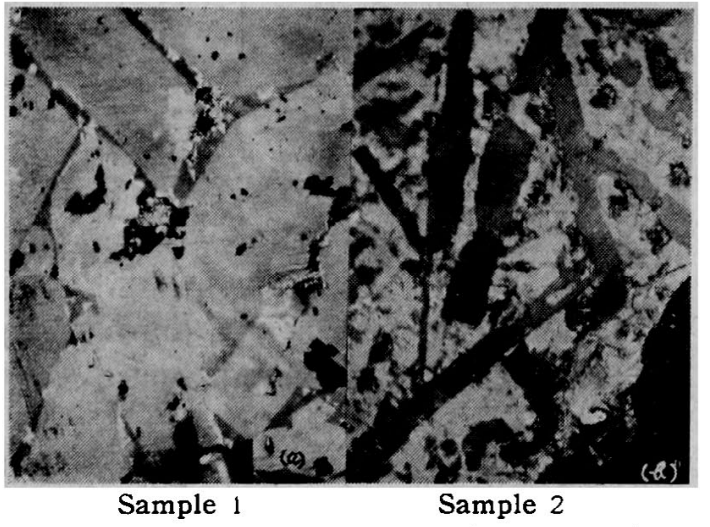

Photo. 7. Microstructures of silicate samples. $\times 400(2 / 3)$ これらの試料の粉末をX線回折した結果, Sample 3〜5 については MnS と FeS が, sample 6 については MnS とわずかに FeS の存在が倠認され几た。

Photo. 8 はこれらの試料を研磨後 $1 \%$ 酒石酸て俩強 した際の光学顕微鏡組織の1例で， sample 4 ては $\mathrm{MnS}$ 固溶体と MnS, FeS 共晶が認められ, sample 6 は $\mathrm{MnS}$ 固溶体から成り粒内に FeS と思力れる微粒が䚽 められる。つぎにこれらの試料を珪酸塩化台物采の場合 と同様にして電子回折した絬果はX線回折の判完とまつ たく同様であつた。一例として sample 5 の電子频微 鏡写真および電子回折像を Photo. 9 に示す. 粉末の電

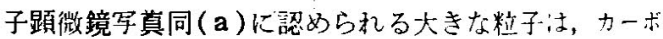
ン膜上に移す際に小粒が凝集したために生じたもので史

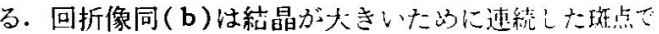

Table 6. Lattice spacings of sample 2.

\begin{tabular}{|c|c|c|c|c|c|c|}
\hline \multirow{2}{*}{ No. } & \multicolumn{2}{|c|}{ Electron diffraction } & \multicolumn{2}{|c|}{$\mathrm{SiO}_{2}(\alpha$-cristobalite $)$} & \multicolumn{2}{|c|}{$\mathrm{MnO} \cdot \mathrm{SiO}_{2}$ (rhodonite) } \\
\hline & Spacing $\AA$ & Int & Spacing $\AA$ & Int & Spacing $\AA$ & Int \\
\hline 1 & $4 \cdot 04$ & $s$ & $4 \cdot 04$ & $1 \cdot 00$ & & \\
\hline 2 & $3 \cdot 54$ & w & & & $3 \cdot 54$ & $0 \cdot 20$ \\
\hline 3 & $3 \cdot 08$ & w & & & $3 \cdot 08$ & 0.60 \\
\hline 4 & $2 \cdot 97$ & $\mathrm{~s}$ & & & $2 \cdot 97$ & 0.90 \\
\hline 5 & $2 \cdot 94$ & s & & & $2 \cdot 94$ & $1 \cdot 00$ \\
\hline 6 & $2 \cdot 74$ & $\mathrm{~m}$ & & & $2 \cdot 76$ & 0.80 \\
\hline 7 & $2 \cdot 46$ & $\mathrm{~m}$ & $2 \cdot 48$ & $0 \cdot 32$ & $2 \cdot 47$ & $0 \cdot 10$ \\
\hline 8 & $2 \cdot 34$ & $\mathrm{~m}$ & & & $2 \cdot 37$ & $0 \cdot 30$ \\
\hline 9 & $1 \cdot 63$ & $\mathrm{~m}$ & $1 \cdot 61$ & $0 \cdot 12$ & $1 \cdot 61$ & $0 \cdot 40$ \\
\hline 10 & $1 \cdot 37$ & $\mathrm{~m}$ & $1 \cdot 37$ & $0 \cdot 03$ & & \\
\hline 11 & $1 \cdot 30$ & $\mathrm{~m}$ & $1 \cdot 30$ & $0 \cdot 03$ & & \\
\hline 12 & $1 \cdot 255$ & $\mathrm{~m}$ & $1 \cdot 235$ & 0.01 & & \\
\hline 13 & $1 \cdot 07$ & $\mathrm{~m}$ & 1.095 & $0 \cdot 03$ & & \\
\hline
\end{tabular}


Table 7. Chemical compositions of sulfide samples $(\%)$.

\begin{tabular}{c|c|c}
\hline No. & MnS & FeS \\
\hline 3 & $15 \cdot 14$ & $89 \cdot 01$ \\
4 & $17 \cdot 91$ & $84 \cdot 50$ \\
5 & $30 \cdot 79$ & $70 \cdot 55$ \\
6 & $83 \cdot 25$ & $34 \cdot 80$ \\
\hline
\end{tabular}

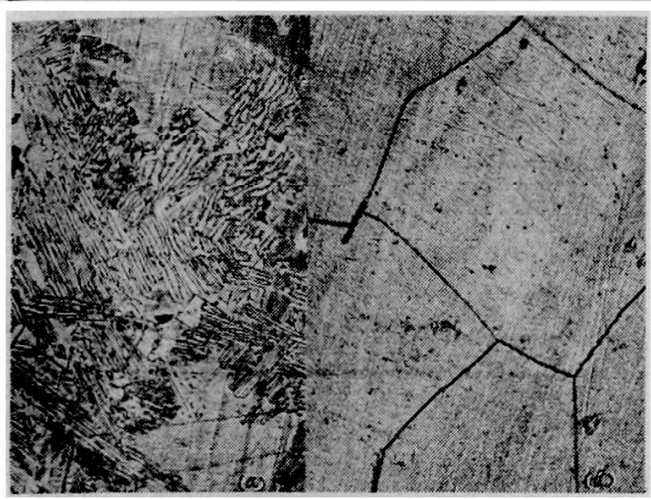

Sample 4

Sample 5

Photo. 8. Microstructures of sulfide samples. $\times 400(2 / 3)$

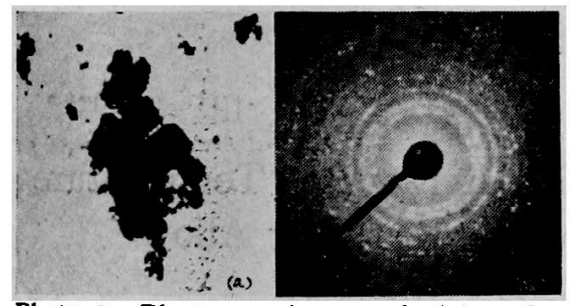

Photo. 9. Electron micrograph (a) and electron diffraction pattern (b) of sulfide sample 5 .

与えられたか， Table 8 のことく解析された。

以上のごとく珪酸塩化会物系および硫化物系合成試料
のいつれについても，カーボン膜上に隺かれたこれらの 粉末の電子回折による同定結果とX線による判定とは完 全に一致し，また電子回折線の相対強度もX線データー に打けるそれと良く一致している。したがつて実際に堸 中に存在する非金属介在物に执いてえられた霆子回折線 の相対強度と $\mathrm{X}$ 線データーにおける相対強度との不一致

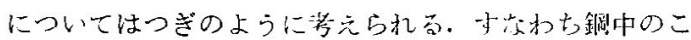
れらの非金属介在物が可延に上り変形忈九る绦に，上く

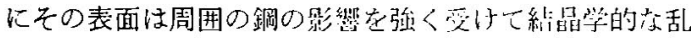
れが生じ，その乱れの影能が耗子回折强庭に現れれたも

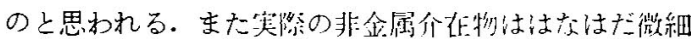

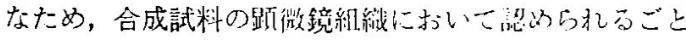
き 2 相共存組織を判则することはできなかつたが，さき に観祭された内部の微細な斑点はこれりの紅䄉を暗示し ているものと考元られる。

\section{V. 総括}

鋼中非金属介在物の判定法上しては，光器影微鏡観

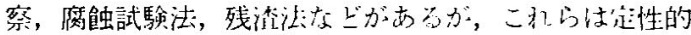

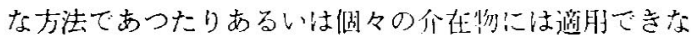
いなどの欠点があり決定的な判定法とはいいがたい，乙 たがつてわれわれは檕受鋼中非金属介任物について上記 試䮖をすると同時に，さらに作物苁エキストラクショ ンレプリカ法により抽出し，これの盗子·四折による同定 を試みた，その結果，A采非金属介在物に対してははと んど全部その楧成物澌を確灾に同定与ることができた。

さらに上の結果を確証するために，上記のごとくして 判明したA系非金属介在物と類似の物留を台成して，こ れについて種々調べてみた。元の維果鋼中の非金属介在 物の同定結果は正しいことが奶ふりりつきのごとき絬論 をうることができた。

朝受鋼中 $\mathrm{A}$ 系非金属介在物は， $\alpha$-クリストバライト

Table 8. Lattice spacings of sample 5.

\begin{tabular}{|c|c|c|c|c|c|c|}
\hline \multirow{2}{*}{ No. } & \multicolumn{2}{|c|}{ Electron diff raction } & \multicolumn{2}{|c|}{$\mathrm{FeS}$} & \multicolumn{2}{|c|}{$\mathrm{MnS}$} \\
\hline & Spacing $\AA$ & Int & Spacing $\AA$ & Int & Spacing & Int \\
\hline $\begin{array}{c}1 \\
2 \\
3 \\
4 \\
5 \\
6 \\
7 \\
8 \\
9 \\
10 \\
11\end{array}$ & $\begin{array}{l}3 \cdot 04 \\
2 \cdot 65 \\
2 \cdot 61 \\
2 \cdot 07 \\
1 \cdot 85 \\
1 \cdot 73 \\
1 \cdot 595 \\
1 \cdot 49 \\
1 \cdot 32 \\
1 \cdot 15 \\
1 \cdot 05\end{array}$ & $\begin{array}{c}\text { s } \\
\text { s } \\
\mathbf{v} \mathbf{s} \\
\mathbf{s} \\
\mathbf{s} \\
\mathbf{s} \\
\mathrm{m} \\
\mathrm{m} \\
\mathrm{w} \\
\mathbf{w} \\
\mathbf{w}\end{array}$ & $\begin{array}{l}2 \cdot 65 \\
2 \cdot 06 \\
1 \cdot 71 \\
1 \cdot 61 \\
1 \cdot 48 \\
1 \cdot 321 \\
1 \cdot 050\end{array}$ & $\begin{array}{l}0.33 \\
1 \cdot 00 \\
0 \cdot 33 \\
0 \cdot 07 \\
0 \cdot 04 \\
0 \cdot 13 \\
0 \cdot 07\end{array}$ & $\begin{array}{l}3 \cdot 02 \\
2 \cdot 61 \\
1 \cdot 85 \\
1 \cdot 58 \\
1 \cdot 51 \\
1 \cdot 17\end{array}$ & $\begin{array}{l}0.11 \\
1 \cdot 00 \\
0.67 \\
0.04 \\
0.20 \\
0 \cdot 23\end{array}$ \\
\hline
\end{tabular}


$\left(\alpha-\mathrm{SiO}_{2}\right)$ とロドナイト，( $\left.\mathrm{MnO} \cdot \mathrm{SiO}_{2}\right)$ の共存状態より なる珪酸塩系介在物と，MnS と FeS の共存状態ある いは MnS 単独状態よりなる硫化物系介在物との 2 つ の柔統に大別された. したがつて珪酸塩介在物の組成は $\mathrm{SiO}_{2}-\mathrm{MnO}$ 采中の $\mathrm{SiO}_{2}$ と $\mathrm{MnO} \cdot \mathrm{SiO}_{2}$ の共存範囲に ありまた硫化物系介在物のそれは-MnS-FeS 系中の $\mathrm{MnS}$ と FeS の共存範囲あるいは MnS 範囲にあるる のと考えられる. 以上の非金属介在物の他に，他の組成 の化合物からなる介在物および電子回折によつては同定 できなかつた介在物がわずかではあるが存在した。

終りに郜み本研究の発表を許可された大河原社套, い ろいろと御教示を賜つた村上先生, 玉置前研究部長，佐

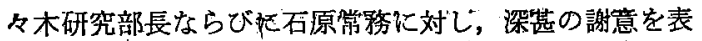
するとともに，分析その他でお世話になつた森脇次長， 松本課員そ.の他の関係各位に御礼申し上げる.

\section{文” . 献}

1) R. M. Fisher; Symposium on Techniqu for Electron Microscope, A.S.T.M., (1953 49

2) 获川，内山，深見；鉄と鋼，43（1957） 1222

3) G. R. Booker,; British J. Appl. Phys., 6 (1955) 430

4) Metals Hand Book, A.S.M., ' (1954) 449

5) A. M. "Portevin \& R. Castro,; J. Iron and Steel Inst., 2 (1936) 21,3

6) J. H. Whiteley; J. Iron and Steel Inst., 160 (1948) 365

7) J. Amer.' Ceram. Sóc., 21 (1938) 121

8) R. Vogel u. W. Hotop; Arch. Eisenhütt., 1 (1.937) 41

(昭和 34 年 2 月奇稿)

\title{
実用 $\mathrm{Ni}$ 基酎熱合金の機械的性質の比較 ${ }^{*}$
}

（Ni 基耐熱合金に関する研究一V)

\section{長 谷川太 郎** \\ Comparison of Mechanical Properties at Elevated Temperature of Some Commercial Ni-base Heat-Resisting Alloys.}

\author{
(Studies on Ni-base heat-resisting alloys-V)
}

\section{Taro Hasegawa}

Synopsis:

Mechanical properties at elevated temperature of six commercial Ni-base heat-resisting alloys were investigated, and the effects of $\mathrm{Co}$, Mo and $\mathrm{Nb}$ on mechanical properties were compared.

When compared the mechanical properties of $\mathrm{Ni}-\mathrm{Cr}$ were with $\mathrm{Ni}-\mathrm{Cr}$-Co alloys, Co was found to be effective to increase strength at high temperature and long time test, and it also increased ductility at room \& elevated temperature.

Mo was found to be effective to increase strength at high -temperature, but it gave effect to decrease at high and long time test. M252 which contained 10\% of Mo was found to have a lower creep rupture strength above $750^{\circ} \mathrm{C}$ than Inco 700 which contained lower Mo, but higher Ti, Al and Co. But M252 had the highest creep ductility at high temperature.

$\mathrm{Nb}$ was found to be effective to increase high-temperature strength as well as $\mathrm{Ti} \& \mathrm{Al}$. But its effect was not clear in short time test of tensile strength. Therefore, Inconel X-550 had the highest stress rupture strength among $\mathrm{Ni}-\mathrm{Cr}$ alloys. Creep ductility was decreased remarkably by the addition of $1.2 \% \mathrm{Nb}$ as $\mathrm{Ni}-\mathrm{Cr}$ alloys which contained high $\mathrm{Ti}$ and $\mathrm{Al}$.

*昭和 33 年 4 月本会講演大会にて発表 ** 住友金属工業 K K製鋼所 